\title{
Umbilical scar autonomization: a safe technique for secondary abdominoplasties
}

\author{
Autonomização da cicatriz umbilical: técnica segura para abdominoplastias \\ secundárias
}

\author{
Liacyr Ribeiro \\ Marcelo Castro Marcal \\ Pessoa $^{2}$ \\ Roberto Braga Rocha ${ }^{2}$
}

Study conducted at the private clinic of the corresponding author, Rio de Janeiro, RJ, Brazil.

Study performed at the private clinic of the corresponding author, Rio de Janeiro, RJ, Brazil.

Received: December 20, 2010 Accepted: January 03, 2011

\begin{abstract}
Background: In lipominiabdominoplasty and mid-abdominoplasty procedures, the umbilicus is usually undermined from its aponeurotic fixation; this modifies its normal vascular pattern. In patients undergoing these procedures and candidates for a secondary classic abdominoplasty, trophic changes, including necrosis, may occur in the umbilical scar. To avoid trophic complications in the neo-umbilicus, autonomization of the umbilical scar was carried out. Methods: Three candidates for a secondary classic abdominoplasty underwent the umbilicus autonomization process in the private clinic of the corresponding author. One incision, $1 \mathrm{~cm}$ from the umbilical scar, was performed from the skin to the aponeurotic plane on each side, with an interval of 15 days between the two surgical incisions. After the second incision, the patient waited for a further 15 days. Thus, the whole process took 30 days before classic abdominoplasty was performed. Results: No trophic alterations or necrosis in the umbilical scar were observed in these cases. Conclusions: The aesthetic results were satisfactory, indicating the effectiveness of this method.
\end{abstract}

Keywords: Umbilicus/surgery. Abdomen/surgery. Necrosis/surgery. Plastic surgery/ methods.

\section{RESUMO}

Introdução: Nos procedimentos de lipominiabdominoplastia e midiabdominoplastia, usualmente, o umbigo é destacado de sua fixação aponeurótica, o que modifica o padrão vascular do umbigo. Em pacientes submetidos a esses procedimentos e candidatos a abdominoplastia clássica secundária, podem ocorrer alterações tróficas da cicatriz umbilical e, até mesmo, necroses. Utilizou-se a manobra de autonomização da cicatriz umbilical para evitar complicações tróficas do neoumbigo. Método: Foram submetidas ao processo de autonomização da cicatriz umbilical 3 pacientes candidatas a abdominoplastia clássica secundária, na clínica privada do autor principal. A técnica compreende uma incisão a 1 $\mathrm{cm}$ da cicatriz umbilical, desde a pele até o plano aponeurótico, de cada lado, com intervalo de 15 dias entre cada etapa, no total de dois tempos cirúrgicos. O processo como um todo leva 30 dias, antes da abdominoplastia clássica. Resultados: Não foram observadas alterações tróficas ou necroses da cicatriz umbilical nos casos submetidos ao processo de autonomização. Conclusões: Os resultados estéticos foram satisfatórios, o que atestou a efetividade do método.

Descritores: Umbigo/cirurgia. Abdome/cirurgia. Necrose/cirurgia. Cirurgia plástica/ métodos. 


\section{INTRODUCTION}

Usually, during mini- and midiabdominoplasty procedures, the umbilical skin flap is disconnected from its anatomic fixation in the midline; this compromises the original vasculature. Autonomization of navel scarring can be used for patients with a medical indication for classical abdominoplasty after undergoing mini- or midiabdominoplasty or to avoid necrosis of the neo-umbilicus or the entire umbilicus. This strategy allows safe and successful conduction of classical abdominoplasty after mini- or midiabdominoplasty.

\section{Motivation for Using this Technique}

In patients who have undergone a miniabdominoplasty or a lipominiabdominoplasty and physical examination of the abdomen shows no umbilical scar, it is unclear whether the navel was sectioned at its aponeurotic base by wider undermining during the previous surgery or if it was kept intact for more economical resection of the skin (Figures 1 to 3 ).

In some cases, such information is provided by the patient or by the surgeon responsible for the previous procedure. If the navel was sectioned at its base, its original vascularization will no longer exist, and its vascular supply will therefore be impaired due to the formation of a random vascular pattern ${ }^{1-5}$ (Figure 4).

Considering this, the authors propose the procedure of umbilical autonomization to increase the security and viability of the navel after a new abdominoplasty.

Our initial motivation for this work was the case of a patient with indication for a classical abdominoplasty and dermal-fat resection above an umbilical scar. In the preoperative examination, the patient presented with a suprapubic scar caused by prior minilipoabdominoplasty,
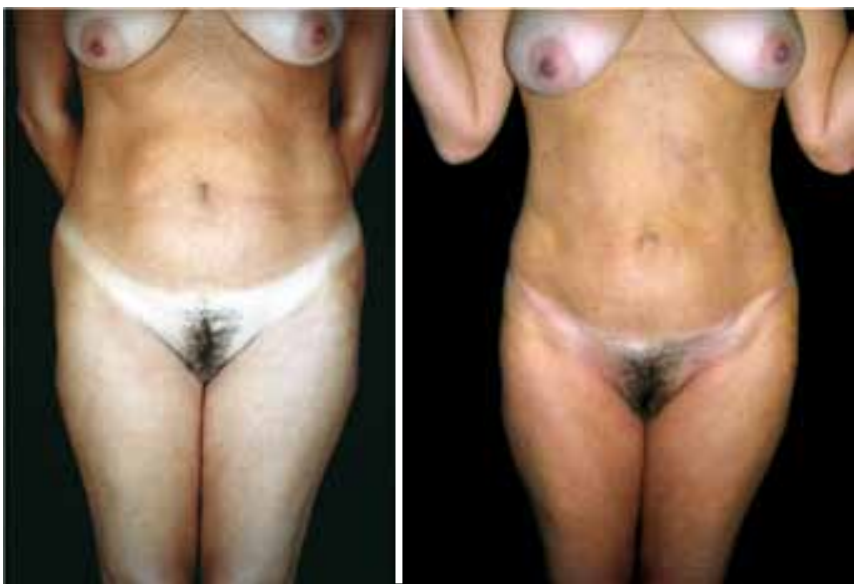

Figure 1 - Front view of pre- and postoperative lipominiabdominoplasty.
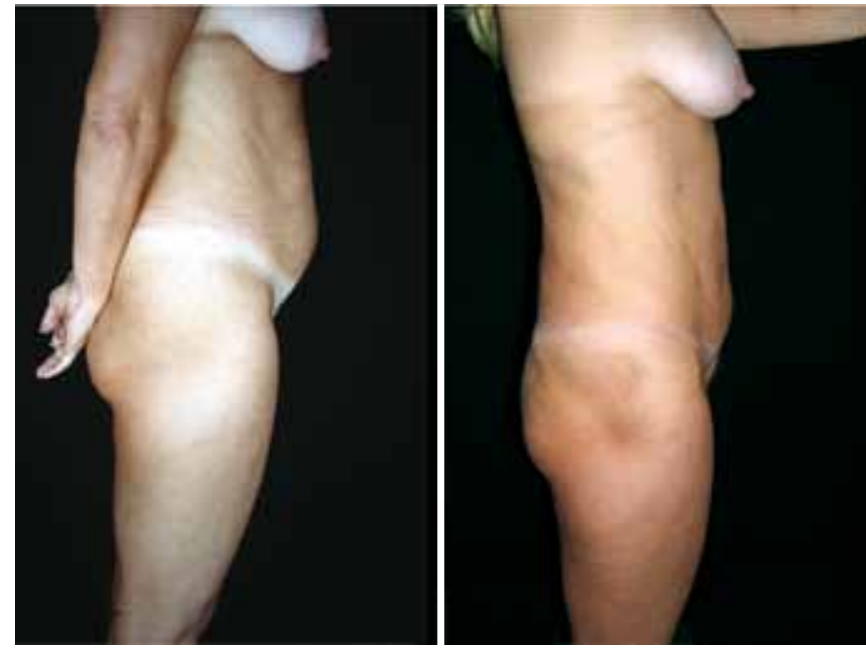

Figure 2 - Lateral view of pre- and postoperative lipominiabdominoplasty.
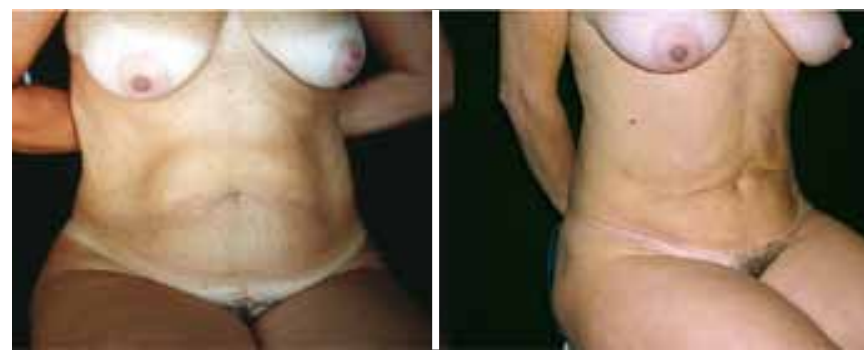

Figure 3-Pre-and postoperative period. Limitation of the lipominiabdominoplasty technique due to excess supraumbilical skin.

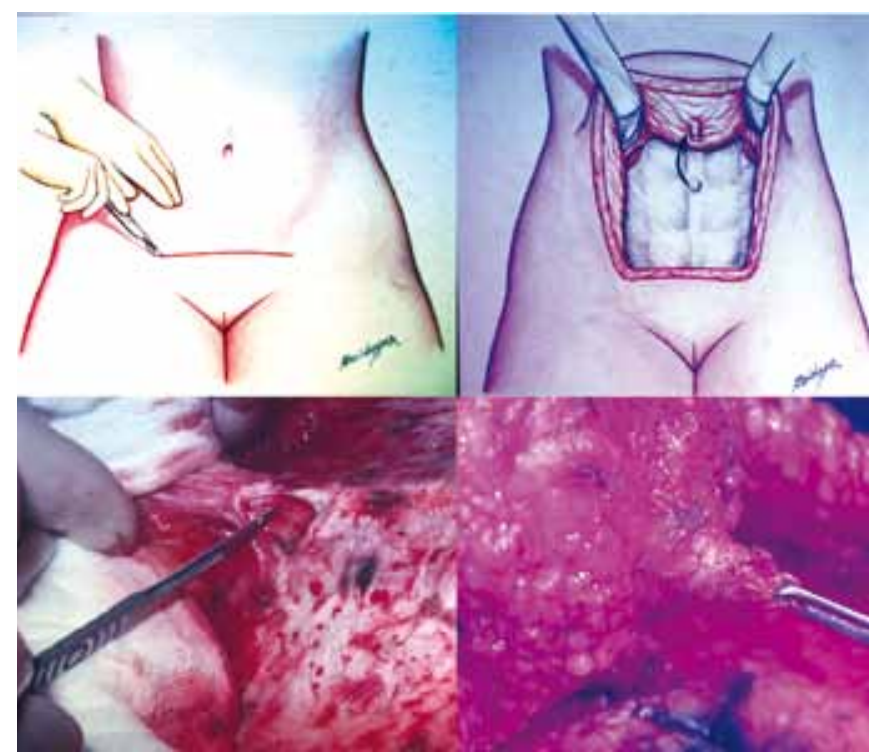

Figure 4 - Surgical sequence of mini- and midiabdominoplasty. Details of undermining of the navel from the abdominal wall. 
combined with resection of a spindle-like suprapubic skin component and plication of the rectus abdominis muscles below the navel. During the postoperative follow-up, trophic alterations were observed to progress to umbilical necrosis. The patient was properly monitored and treated, with subsequent reconstruction of the umbilicus.

Despite the resolution of this case, the authors concluded that umbilical necrosis could have been avoided with use of the autonomization technique to prepare the skin flaps, a commonly used resource for transverse rectus abdominis myocutaneous (TRAM) flap breast reconstruction, which is carried out to increase the survival and regeneration chances of the skin flaps.

\section{Anatomical Principles}

Several authors have tried to map the exact anatomy of the arterial supply to the navel, with emphasis on the clinical application of reconstruction using the TRAM flap. The deep inferior epigastric artery is responsible for the main arterial supply to the lower abdominal wall. The arterial supply of the navel consists of three main deep sources and the subdermal vascular plexus.

The main deep sources are as follows:

- the right and left epigastric arteries. These result in perforating branches and an ascending branch, which runs between the muscle and the aponeurotic posterior leaflet of the rectus abdominis muscle, straight to the navel;

- the ligamentum teres hepatis;

- the median umbilical ligament.

The subdermal plexus of the umbilical region is supplied by the perforating branches of the right and the deep epigastric arteries on the left and is mostly located laterally and beneath the navel, with an average distance of $4 \mathrm{~cm}^{6}$. These perforating branches are the vessels responsible for the vascular volume of the skin island of the TRAM flap. Based on practical experience in TRAM flap breast reconstructions, the same principles were used for aesthetic surgery in cases with indication for classical abdominoplasty after mini- or midiabdominoplasty.

\section{METHODS}

The process of autonomization of the umbilicus was indicated in three cases from the private clinic of the authors. These patients had undergone prior miniabdominoplasty associated with liposuction, suprapubic skin resection, plication of the rectus abdominis muscles and, most importantly, undermining of the umbilicus at the muscular fascia level with posterior fixation 1 to $2 \mathrm{~cm}$ below its anterior position (Figure 5).

After the selection of these female patients, the initiation of the autonomization procedure was scheduled approximately 30 days before definitive surgery.
In an outpatient setting and under local anesthesia, an incision was made in the paraumbilical region using a scalpel and extended unilaterally through the cutaneous and subcutaneous levels to the fascia, keeping a distance of approximately $1 \mathrm{~cm}$ from the lateral margin of the umbilical cavity, the zone that contains the vasculature for the umbilical flap. Hemostasis was reviewed, and the skin was sutured with simple stitches using 5.0 nylon (Figures 6 to 8). The contralateral side was treated in the same way 15 days later, and the patient waited another 15 days so the process could be completed (Figures 9 to 13). At the end of this process, patients could be operated on safely (Figure 14).

Classical abdominoplasty was performed with resection of the skin and fat prior to umbilical autonomization and elevation of the dermal-fat flap to the xiphoid appendix, along with

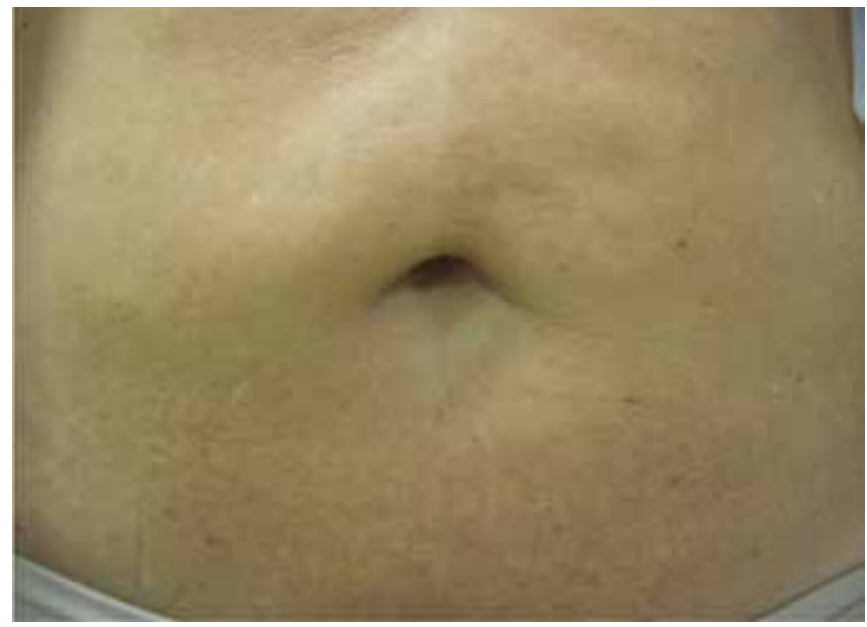

Figure 5 - Detail of navel resulting from lipominiabdominoplasty. Pre-autonomization view.

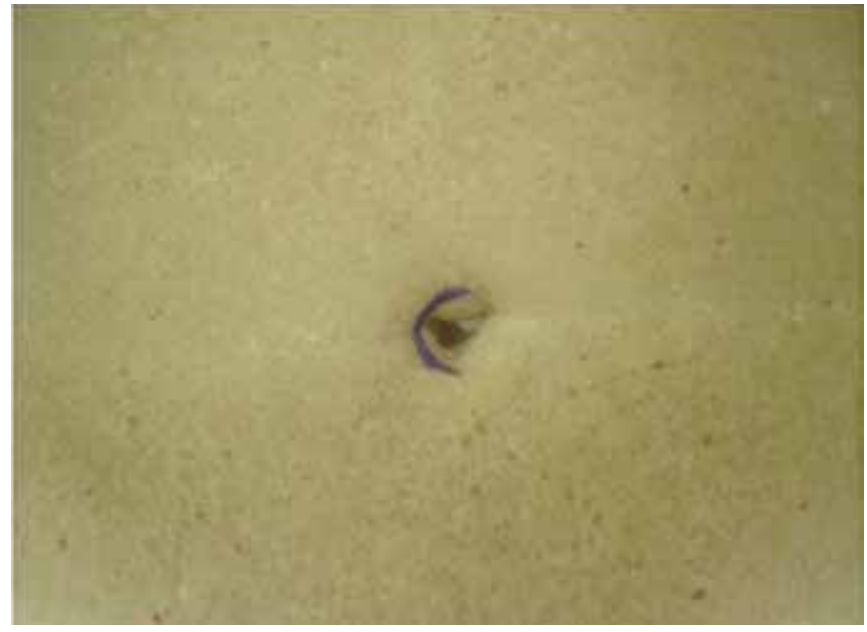

Figure 6 - Incision line highlighting the first side to be autonomized. First operative step. 


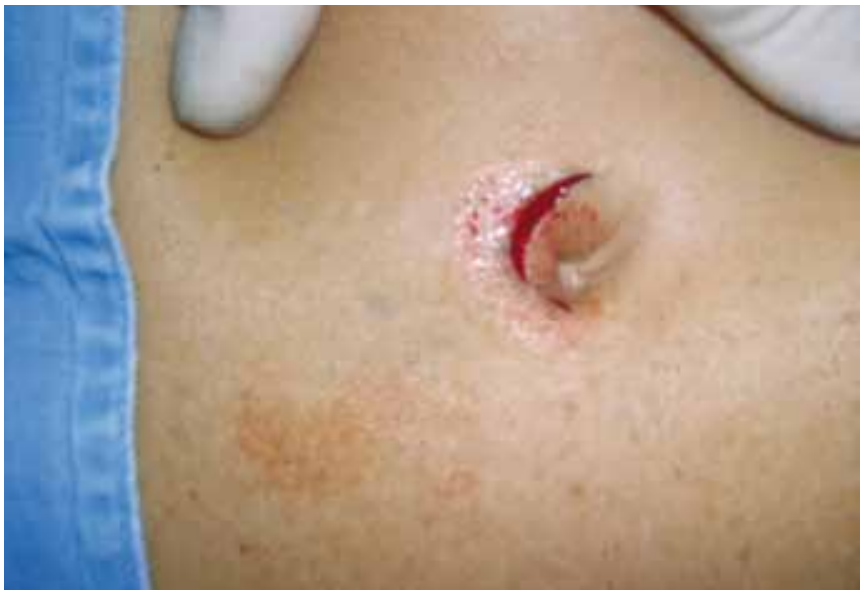

Figure 7 -Detail of the skin incision on the first side, with undermining until the muscular fascia.

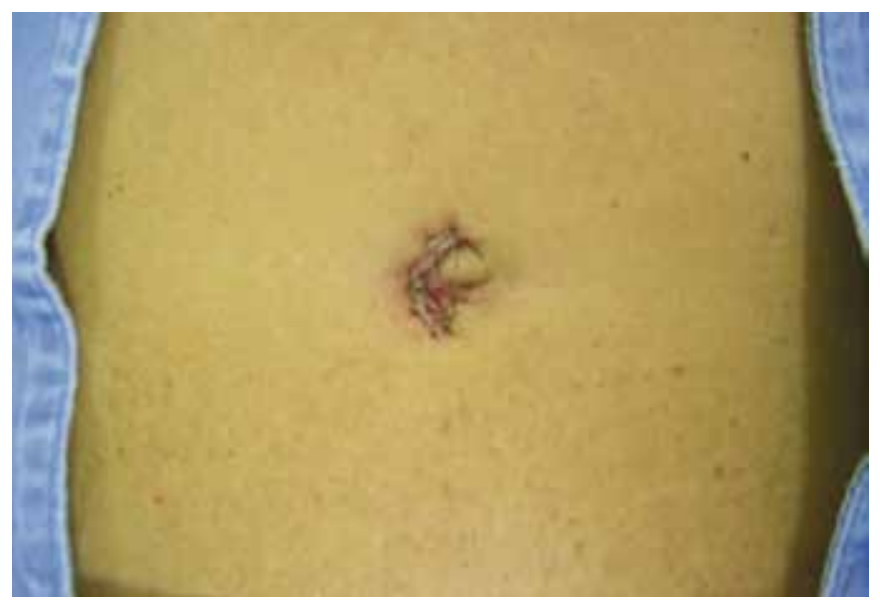

Figure 8 - Suture of the skin on the first autonomized side.

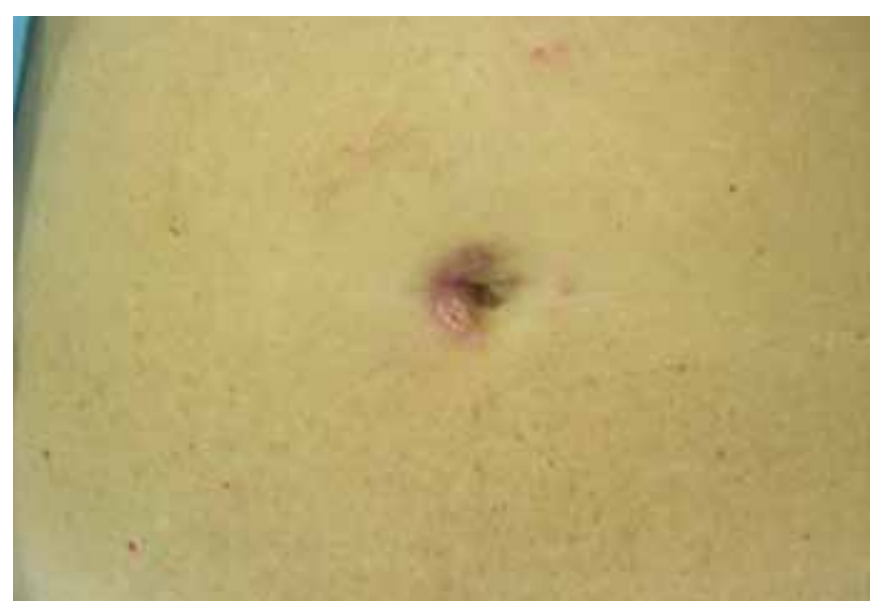

Figure 9 - Detail after removal of skin sutures on the first side.

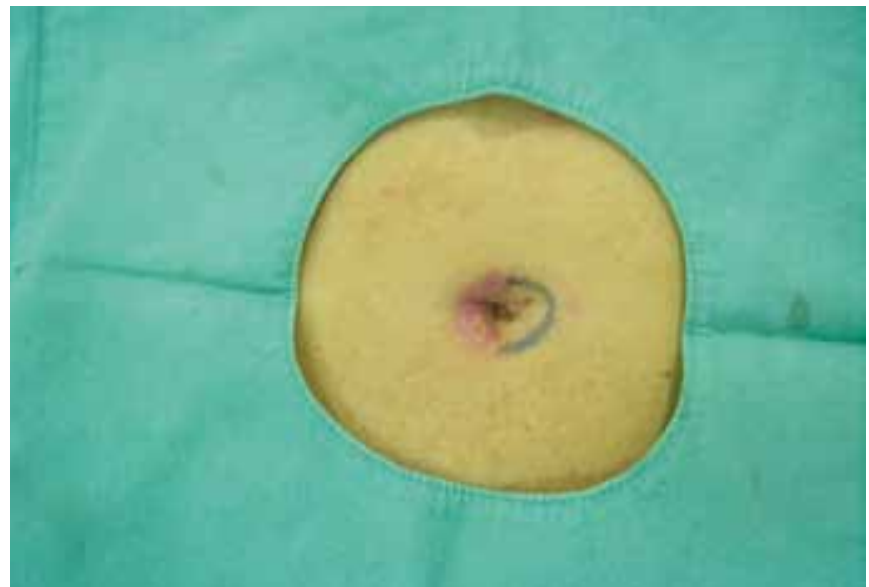

Figure 10 - After 15 days, autonomization of the second side. Incision line indicating the second side to be autonomized.

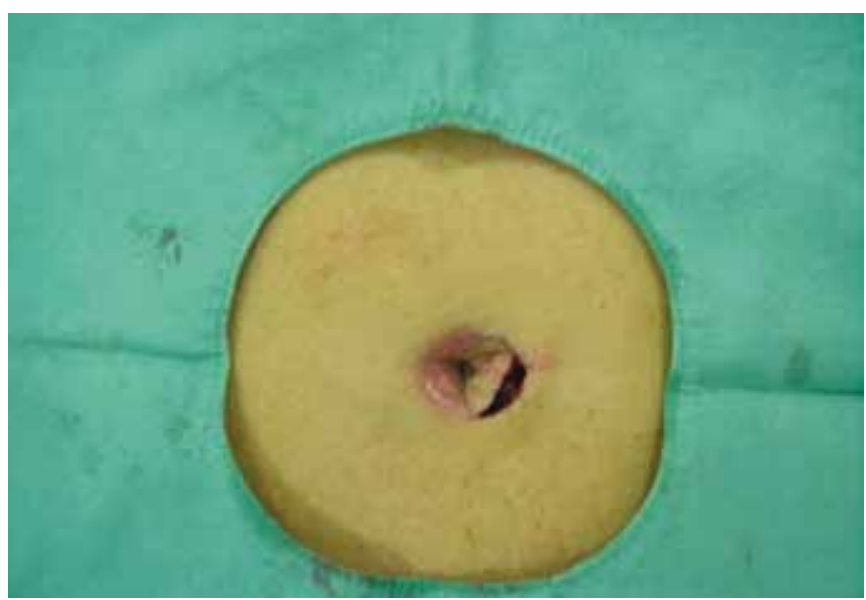

Figure 11 - Detail of the skin incision on the second side, up to the muscular level.

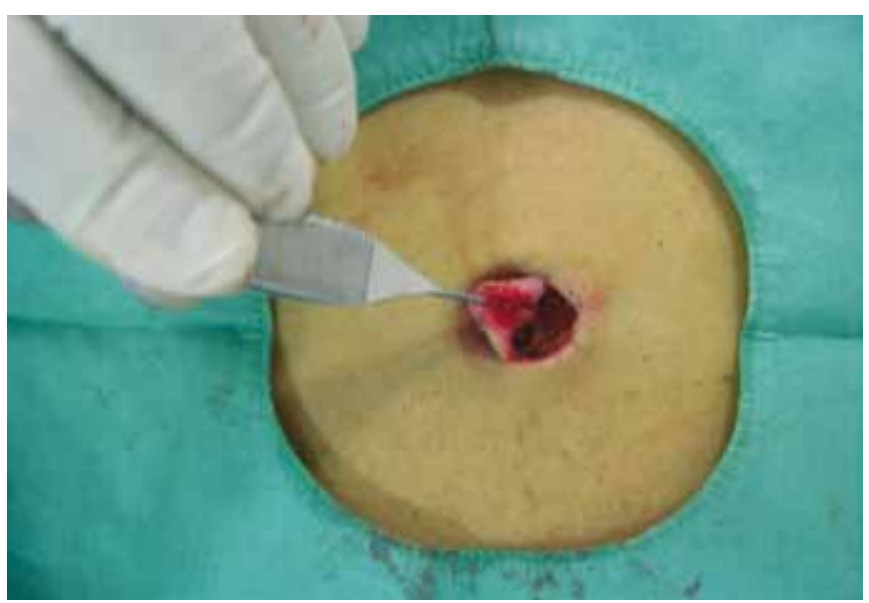

Figure 12 - Detail of lateral displacement up to the muscular level. 


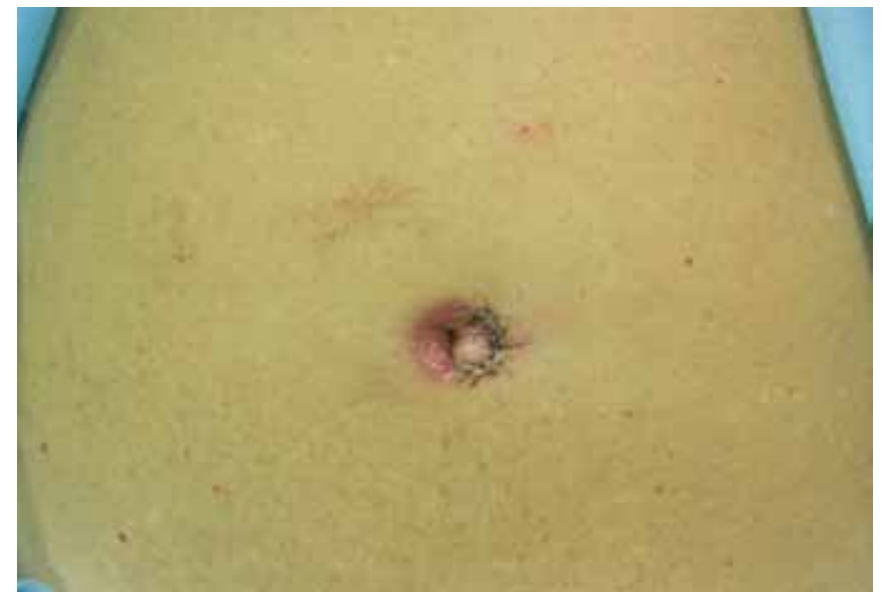

Figure 13 - Suture of the skin on the second autonomized side.

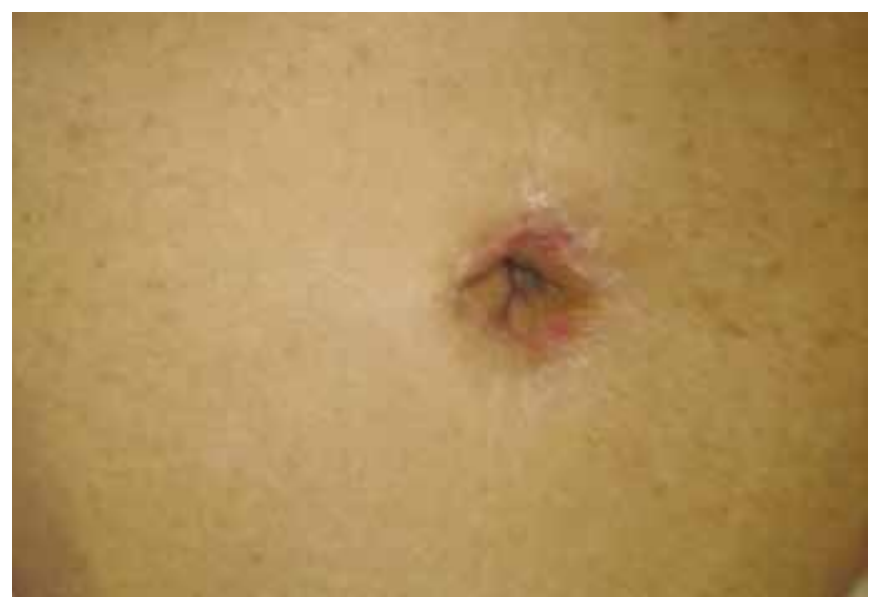

Figure 14 - Process of complete autonomization 30 days after the two surgical steps.

plication of the rectus abdominis muscles (Figures 15 to 17).

The circular shape of the umbilical cutaneous flap was maintained during the omphaloplasty, and to protect the vessels of the flap, the flap was fixed to the aponeurosis using simple stitches of 3.0 nylon at the cardinal points, with care being taken not to harm tissue nutrition. Next, the point of exteriorization of the neo-umbilicus was marked by an approximately $2 \mathrm{~cm}$ horizontal incision, with subsequent circumferential degreasing in order to decrease the amount of tissue and consequent tension on the suture with the umbilical flap (Figure 18).

Following this, stitches were performed according to the method of Baroudi et al. ${ }^{7,8}$ to decrease the dead space and fix the abdominal flap to the aponeurosis. The neo-umbilical skin was then sutured using 8 simple stitches of 5.0 nylon. The suprapubic scar was sutured plane by plane from Scarpa's fascia to the skin using suction drains and padded bandages.

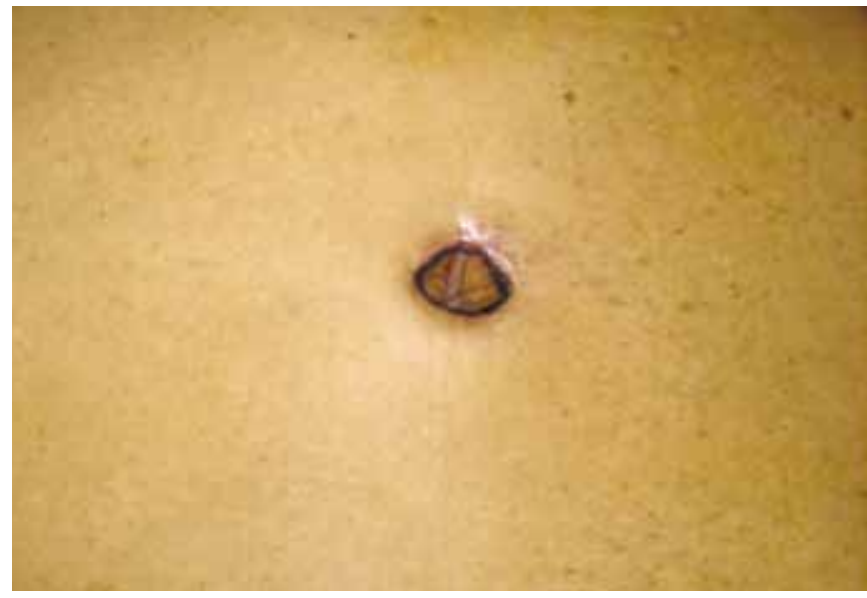

Figure 15 - Marking of navel autonomization after classic abdominoplasty.

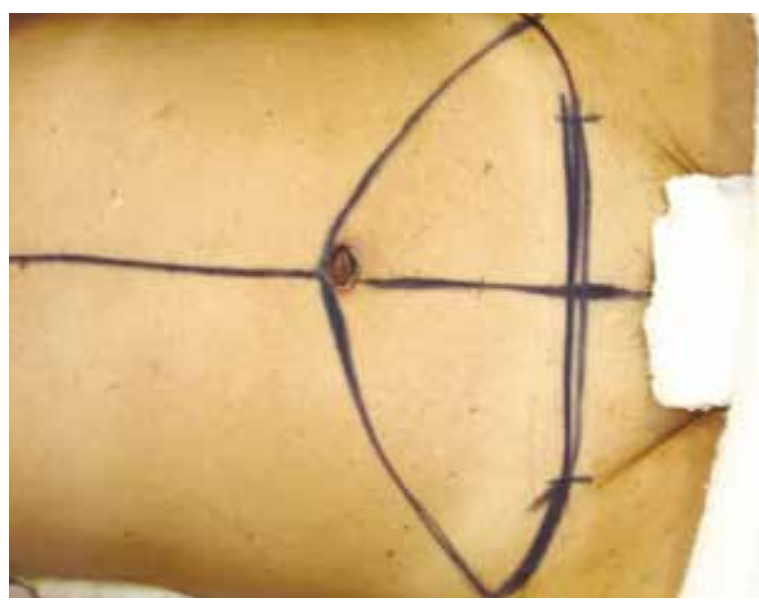

Figure 16-Marking of the flap to be resected. Classic technique of abdominoplasty.

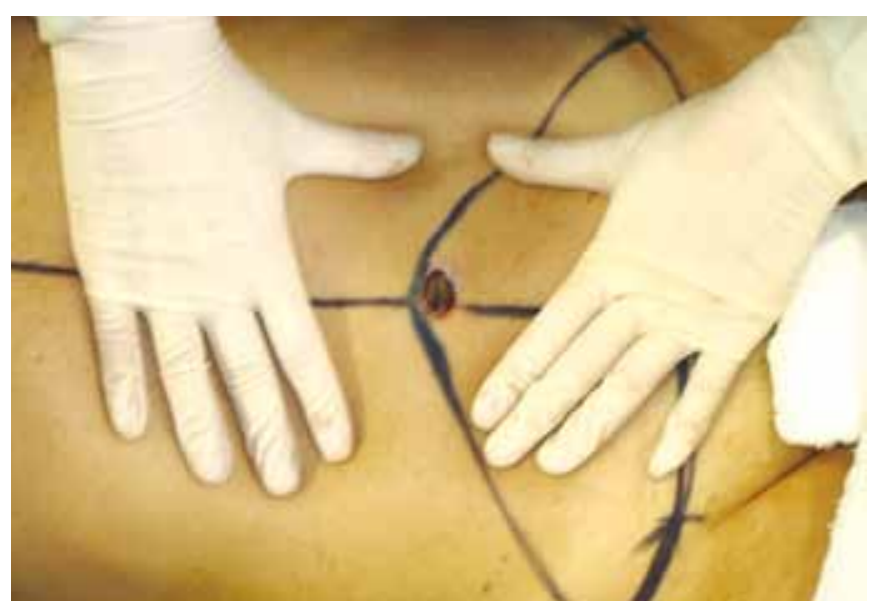

Figure 17 - Circular incision in navel flap autonomization. 


\section{RESULTS}

The patients recovered satisfactorily without complications and with the expected aesthetic benefits. There were no trophic alterations or umbilical necrosis in the patients who underwent the autonomization process.

Figures 19 to 29 illustrate the cases in which the described technique was used.

\section{DISCUSSION}

Autonomization is a method that increases the survival potential of cutaneous flaps. However, due to knowledge of the axial vascular pattern and angiosomes and the use of musculocutaneous, fasciocutaneous, and microsurgical flaps, the importance of autonomization has diminished in recent years. Autonomization has been extensively studied by several researchers, with contradictory and/or nonreproducible results ${ }^{9,10}$.

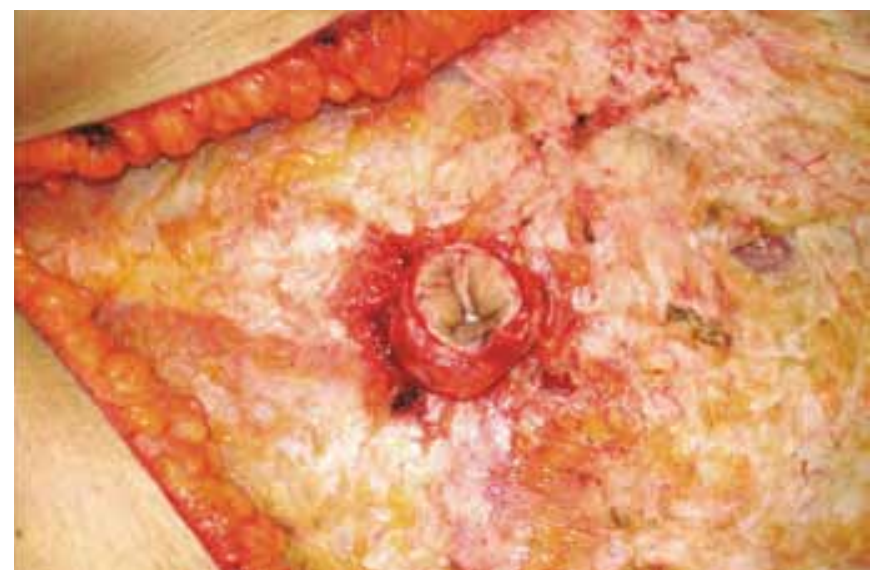

Figure 18 - Detail of the umbilical flap after undermining of the
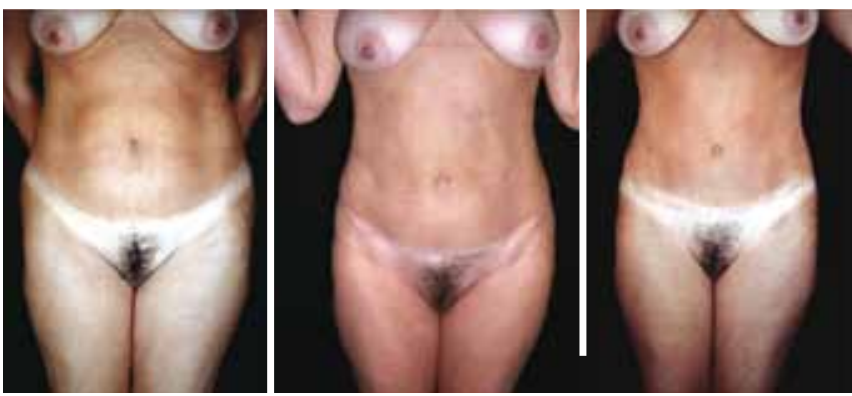

Figure 19 - Comparative result of a patient who underwent lipomidiabdominoplasty and posterior classical abdominoplasty with autonomization of the umbilical flap.

Pre- and postoperative lipomidiabdominoplasty and classical abdominoplasty with autonomization of the navel.
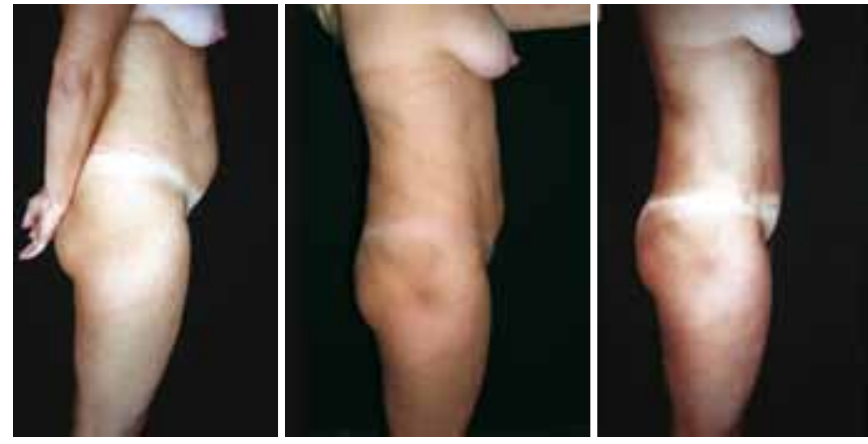

Figure 20 - Lateral view of pre- and postoperative lipomidiabdominoplasty and classical abdominoplasty with autonomization of the navel.

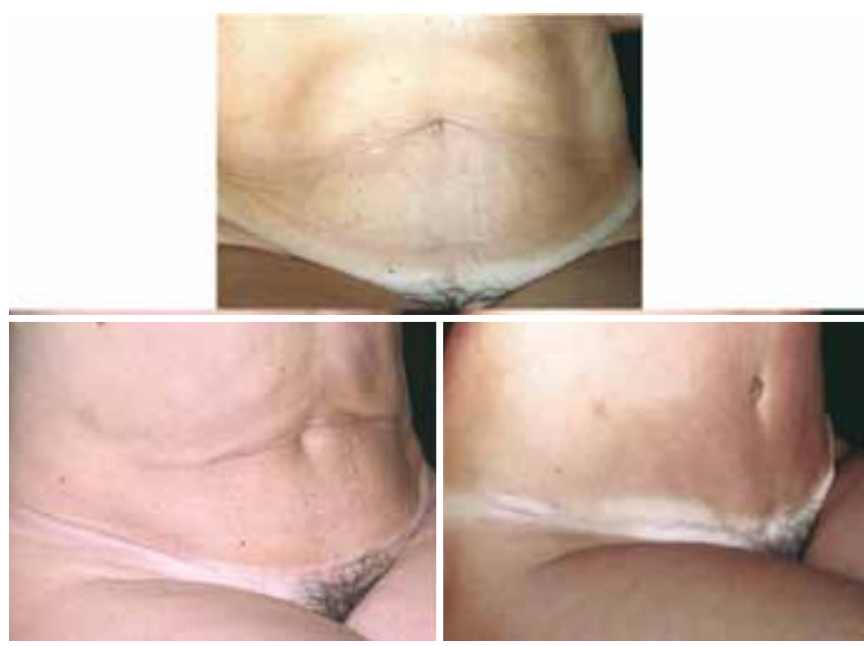

Figure 21 - Comparative results of pre-and postoperative lipomidiabdominoplasty and classical abdominoplasty with autonomization of the navel.

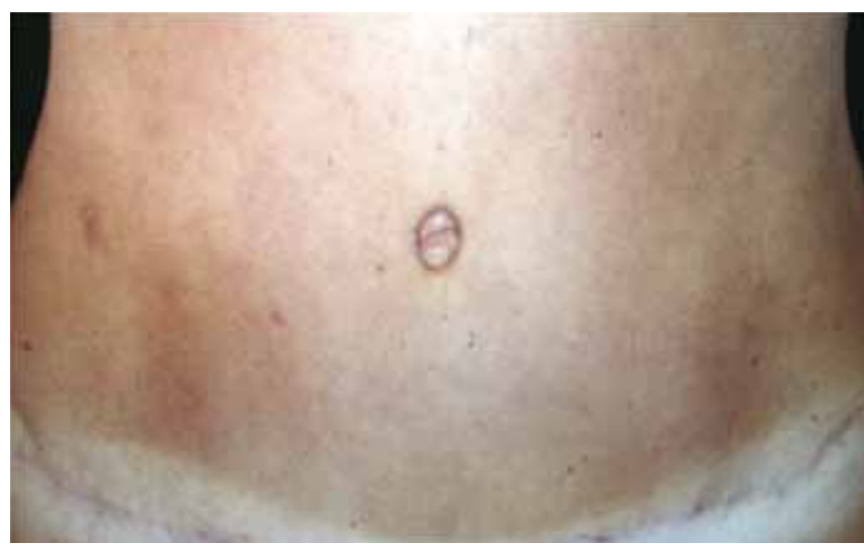

Figure 22 - Detail of the umbilicus resulting from classical abdominoplasty after autonomization of the navel. Perfect viability of the autonomized navel flap. 
The mechanism of autonomization occurs via partial disruption of the vasculature in the distal limits of a cutaneous flap, before complete lift and transfer of the flap. This process increases the blood flow in the tissue and the tolerance of the flap to hypoxic conditions ${ }^{11}$.
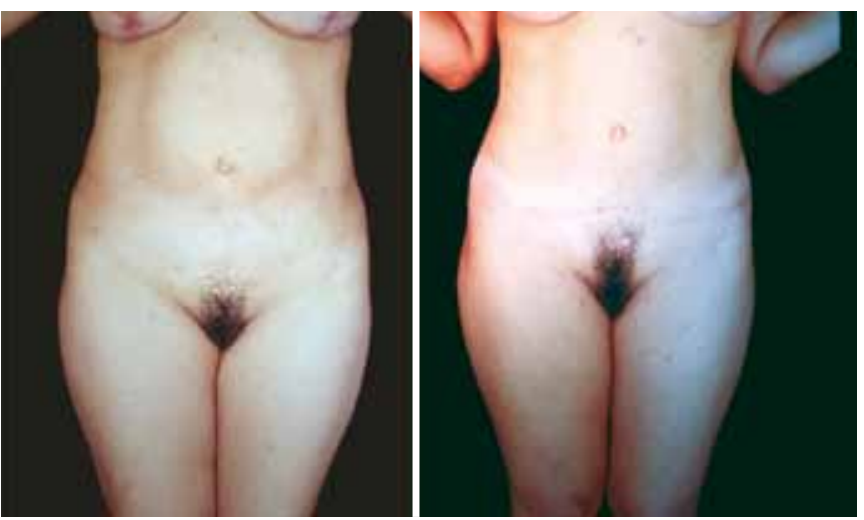

Figure 23 - Case report. Front view of postoperative miniabdominoplasty and classical abdominoplasty with autonomization of the navel and mastopexy with breast implants (4 months).

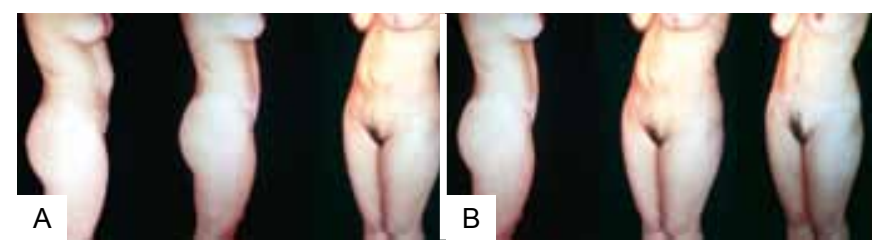

Figure 24 - Pre-and postoperative secondary abdominoplasty with autonomization of the navel. Lateral view (A) and oblique view (B).
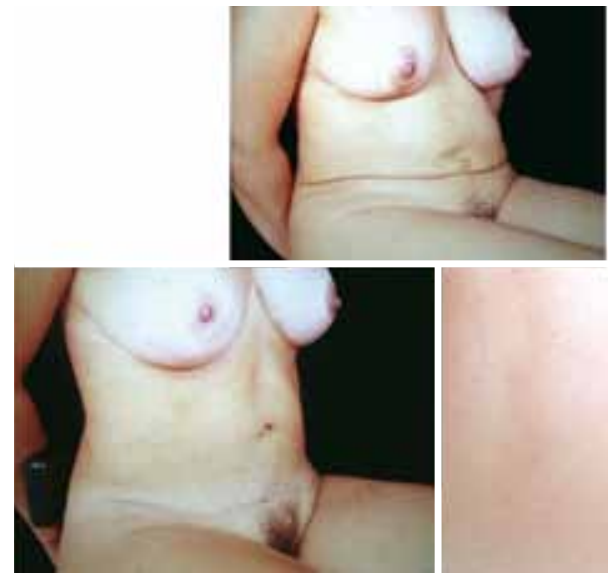

Figure 25 - View in the sitting position after autonomization of the navel and new abdominoplasty.

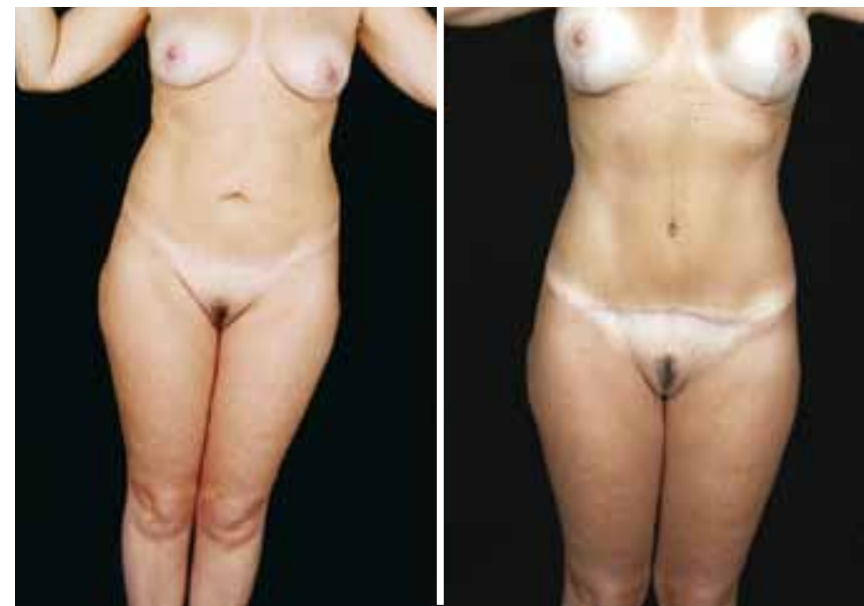

Figure 26-Front view of pre- and postoperative secondary abdominoplasty with autonomization of the navel and mastopexy with breast implants.

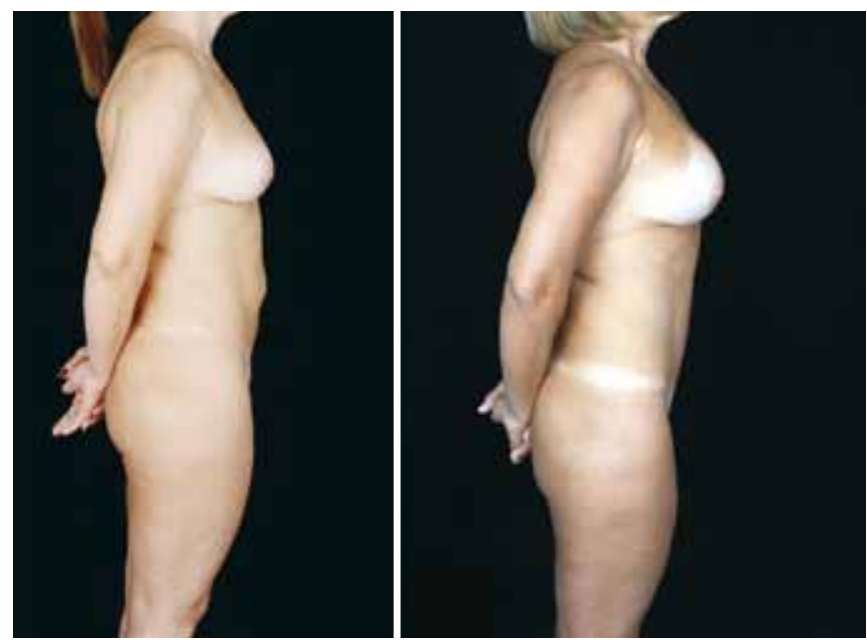

Figure 27 - Lateral view.

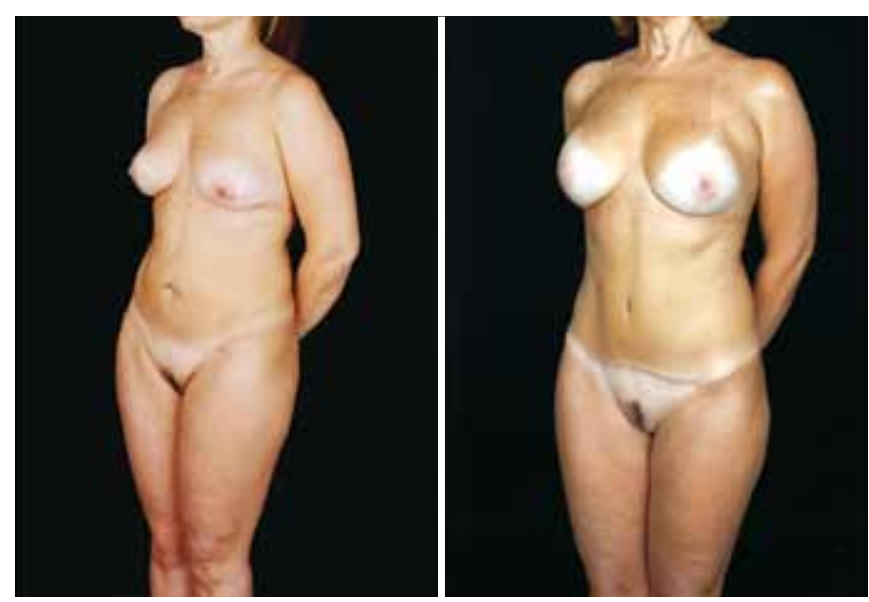

Figure 28-Oblique view. 


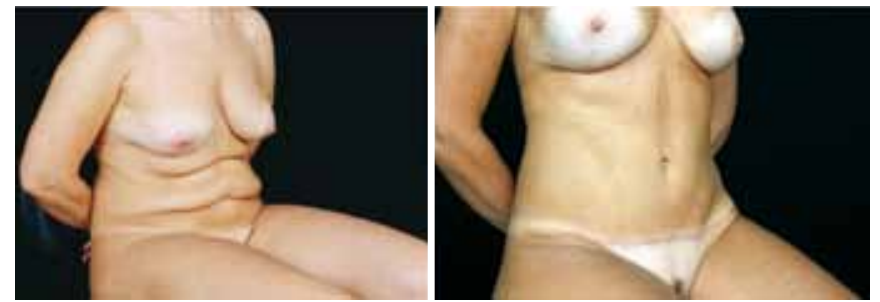

Figure 29 - View in the sitting position. In A, pre-operative excess skin after lipomidiabdominoplasty.

After autonomization, researchers have observed an increase in the caliber and number of vessels, redirection of flow patterns, and improvement in local blood flow. Some authors have also reported a transient increase in local blood vessels in response to a state of relative hypoxemia and arteriovenous shunt in the areas closest to the cutaneous flaps ${ }^{12,13}$.

Experimental studies indicate that the maximum increase in local blood flow occurs around the seventh day after autonomization. The waiting time between autonomization and flap elevation varies from 10 days to $3-4$ weeks $^{14,15}$. The reported mechanisms underlying adaptation in skin flaps subjected to autonomization are somewhat contradictory; however, all studies have reached a consensus about the effectiveness of the method.

Therefore, based on the available information in favor of the effectiveness of the flap autonomization method, we provide theoretical support for the use of autonomization for the umbilical scar in patients undergoing abdominoplasty after mini- or midiabdominoplasty ${ }^{16,17}$.

\section{CONCLUSION}

Follow-up of the three cases in this study revealed successful preservation of the umbilical flaps after autonomization, without any complications.

With the application of a currently underused, and even forgotten, concept, we consider that it is possible to avoid umbilical necrosis in patients with questionable integrity of the primary vascular pattern of the navel, especially in patients who have already undergone aesthetic surgery of the abdomen and in cases of mini- or midiabdominoplasty.

The autonomization procedure was chosen because it is a simple and safe method that can be used to avoid complications such as umbilical necrosis after aesthetic surgery of the abdomen.

\section{REFERENCES}

1. Avelar J. Abdominoplasty: systematization of a technique without external umbilical scar. Aesthetic Plast Surg. 1978;2(1):141-51.

2. Avelar JM. Lipoaspiração: nova e valiosa contribuição à abdominoplastia. Ressecção cutânea infra-umbilical com seccionamento do pedículo do umbigo. Rev Bras Cir. 1986;76:221-7.

3. Gradel J, Carreirão S, Branco C, Cintra H. Reconstrução da parede abdominal com tela de prolene (em zona doadora do retalho miocutâneo do músculo reto abdominal). Rev Bras Cir. 1986;76:189.

4. Grazer F. The miniabdominoplasty (discussion). Plast Reconstr Surg. 1987;79:365.

5. Pitanguy I. Abdominal lipectomy. Clin Plast Surg. 1975;2(3):401-10.

6. Stokes RB, Whetzel TP, Sommerhaug E, Saunders CJ. Arterial vascular anatomy of the umbilicus. Plast Reconstr Surg. 1998;102(3):761-4.

7. Baroudi R. Management of the umbilicus in abdominoplasty. Presented at Society Aesthetic Plastic Surgery Meeting; 1973.

8. Baroudi R, Keppke EM, Netto FT. Abdominoplasty. Plast Reconstr Surg. 1974;54(2):161-8.

9. Wilkinson TS, Swartz BE. Individual modifications in body contour surgery: the "limited" abdominoplasty. Plast Reconstr Surg. 1986;77(5):779-84

10. German W, Finesilver EM, Davis JS. Establishment of circulation in tubed skin flaps: an experimental study. Arch Surg. 1933;26(1):27-40.

11. Myers MB. Attempts to augment survival in skin flaps-mechanism of the delay phenomenon. In: Grubb WC, Myers MB, eds. Skin flaps. Boston: Little, Brown; 1975. p. 65-79.

12. Myers MB, Cherry G, Milton S. Tissue gas levels as an index of the adequacy of circulation: the relation between ischemia and the development of collateral circulation (delay phenomenon). Surgery. 1975;71(1):15-21.

13. Reinisch JF. The pathophysiology of skin flap circulation. The delay phenomenon. Plast Reconstr Surg. 1974;54(5):585-98.

14. Guba AM Jr. Study of the delay phenomenon in axial pattern flaps in pigs. Plast Reconstr Surg. 1979;63(4):550-4.

15. Gillies HD, Millard DR. The principles and art of plastic surgery. Boston: Little, Brown; 1957.

16. Ribeiro L. Tratatamento da gordura nas abdominoplastias. Anais $1^{\mathrm{o}}$ Simpósio Brasileiro de Abdominoplastia. São Paulo; 1982.

17. Ribeiro L, Muzy S, Accorsi A. Omphaloplasty. Ann Plast Surg. 1991; $27(5): 457-75$

\section{Correspondence to:}

Liacyr Ribeiro

Rua Visconde de Silva, 52 - $9^{\circ}$ andar - salas 903 e 904 - Botafogo - Rio de Janeiro, RJ, Brazil - CEP 22271-090

E-mail: ribeiroliacyr@globo.com 